\title{
PREFERENSI TIKUS SAWAH (RATTUS-RATTUS ARGENTIVENTER) DAN PENGARUHNYA TERHADAP POLA KERUSAKAN PADI VARIETAS DODOKAN DAN CIANJUR
}

\author{
Solikhin $^{1}$ dan Purnomo ${ }^{1}$
}

\begin{abstract}
Paddyfield Rat (Rattus-rattus argentiventer) Preference and Its Impact on The Damage Pattern of Dodokan and Cianjur Rice Cultivar. A field experiment was conducted during the dry season of 2006 in Central Lampung to evaluate the preference of paddyfield rat (Rattus-rattus argentiventer) to Dodokan and Cianjur rice cultivars in the rice field and its impact on the damage pattern caused by the rat's attack. The experiment of six treatments and 3 replications were arranged in a randomized completely block design. Each treatment consisted of two rice cultivars i.e. Cisadane and Dodokan. Dodokan cultivar was planted in centre of each experimental unit, surrounded by Cianjur, forming six different patterns (formations) as treatment. All experimental units then were exposed to natural paddyfield rat population. Weekly observations on both cultivars were made to record the damage caused by the rat from 30 to 84 day after transplanting. Aerial view of all treatments were also taken at 84 days after transplanting (a week prior to harvest). The result showed that the paddyfield rat significantly prefered Dodokan rice cultivar to Cianjur. Eventually, the preference of the rat influenced the damage pattern of Dodokan rice cultivar, showed by some unique aerial views of the plot.
\end{abstract}

Key words : Rattus-rattus argentiventer, preference, dodokan, damage pattern

\section{PENDAHULUAN}

Salah satu kendala utama dalam budidaya tanaman padi adalah adanya serangan hama tikus (Rattus-rattus spp.), terutama pada musim tanam gadu atau musim kemarau. Berdasarkan peringkat yang dibuat oleh Gedes (Singleton \& Petch, 1994) hama tikus di Indonesia menempati urutan pertama pada pertanaman padi, kemudian diikuti oleh penggerek batang, wereng coklat, dan walang sangit. Peringkat tersebut juga memperlihatkan bahwa di Asia Tenggara tikus juga menempati urutan pertama, diikuti oleh hama-hama utama yang lain dengan peringkat yang hampir sama.

Berdasarkan laporan dari Laboratorioum pengamatan Hama dan Penyakit Trimurjo (1999), di Lampung Tengah dari musim tanam 1989/1990 sampai 1999/2000 ada 20 musim tanam, ternyata 19 musim tanam di antaranya terserang tikus dengan intensitas ringan sampai puso. Dengan kata lain, pada hampir semua musim tanam serangan tikus menjadi masalah dalam budidaya padi. Selanjutnya dilaporkan bahwa dari 19 musim tanam tersebut memang tidak semua kecamatan terserang, tetapi hal ini mengindikasikan bahwa serangan hama tikus pada pertanaman padi perlu untuk dikaji lebih lanjut. Kerugian yang diakibatkan oleh serangan tikus menyebabkan petani yang mengambil kredit usaha tani (KUT) tidak mampu mengembalikan kredit karena tanaman padi mengalami puso pada tahun 1999. Harahap \& Tjahjono (1995) melaporkan bahwa kehilangan hasil oleh tikus di Asia Tenggara berkisar 5 sampai 60\%. Namun sebenarnya kehilangan hasil ini bisa mencapai $100 \%$ karena tanaman menjadi puso, terutama pada musim kemarau.

Pola umum kerusakan (serangan) tikus di areal persawahan biasa ditemukan menyerupai stadion sepakbola dengan bagian tengah lebih pendek karena rusak terserang dan sering menyisakan bagian pinggir saja yang tidak terserang (Gambar 1). Pola tersebut tampaknya tidak hanya berlaku (bisa terjadi) pada varietas padi yang disukai tikus, tetapi juga pada varietas padi yang kurang disukai tikus, dengan syarat jika areal tersebut ditanami varietas yang seragam.

Pada pengamatan adaptasi berbagai varietas padi di tanah rawa tahun 2000 diperoleh hasil berupa pola kerusakan hasil yang khas yang disebabkan oleh serangan tikus sawah. Pertanaman yang terdiri atas enam varietas padi pada beberapa petak tersebut menunjukkan adanya pola kerusakan yang selalu mengikuti jenis atau varietas padi Dodokan. Varietas padi yang ditanam adalah Atomita, Cempo Lombok, IR64, Ciliwung, Dodokan, dan Cianjur. Varietas Dodokan pada semua ulangan selalu mendapat

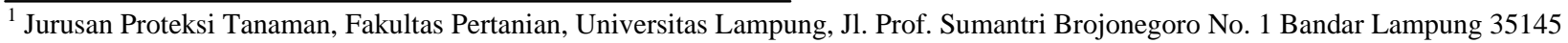




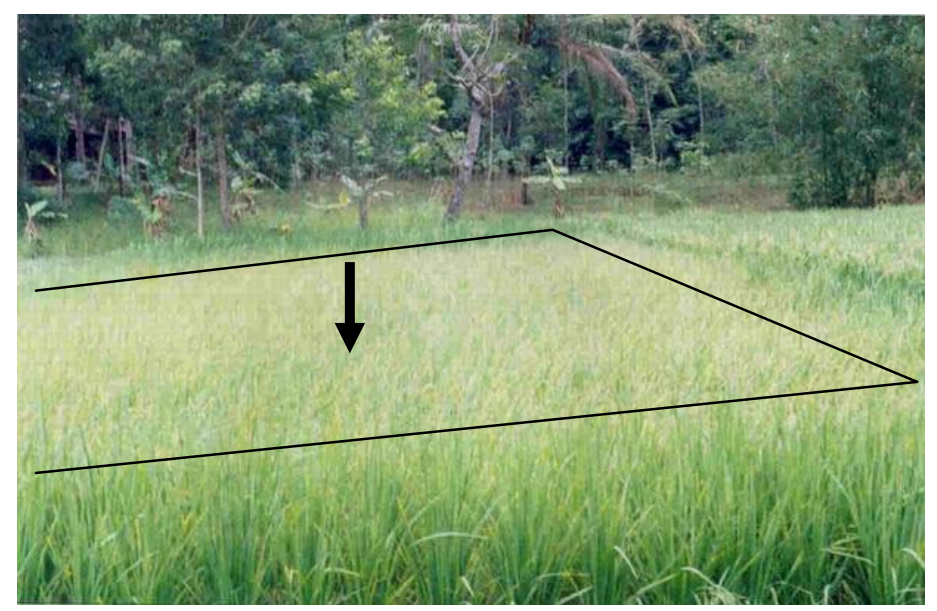

Gambar 1. Pola serangan tikus menyerupai stadion sepakbola pada varietas Cisadane

intensitas serangan yang sangat berat, bahkan ada yang sampai 100 persen, sementara varietas-varietas yang lainnya hanya mengalami intensitas serangan ringan. Serangan tikus selalu tertuju pada varietas Dodokan ini. Jika semua anakan pada rumpun sudah habis terserang (terpotong) maka tikus akan menyerang rumpun singgang (rattoon) varietas Dodokan lain yang sudah mulai tumbuh, tidak menyerang rumpun varietas lain di sekitarnya . Demikian tejadi seterusnya berulang-ulang sampai panen sehingga tikus hanya menyerang atau terkonsentrasi pada varietas Dodokan saja.

Di daerah Tamanbogo, Lampung Timur, tikus selalu menyerang varietas Widas dengan intensitas serangan tertinggi (50\%), padahal pada areal tersebut terdapat beberapa varietas lain yang berbeda. Ternyata varietas Dodokan dan Widas memang berumur lebih pendek (genjah), yaitu berumur 80 hari setelah tanam (hst) bisa dipanen, dibandingkan lima varietas yang lain yang umur panennya lebih lama (dalam). Dengan kata lain varietas Widas dan Dodokan mempunyai persamaan, yaitu sama-sama berumur pendek sehingga lebih cepat mencapai fase primordia dan disenangi oleh tikus.

Pada tingkat serangan yang tinggi, tikus hanya menyisakan tanaman selebar satu meter dari pematang mengikuti arah pematang tersebut. Pola kerusakan yang ditimbulkan masih mirip dengan pola kerusakan yang umum (mirip stadion). Pernah terjadi hal yang menarik ketika varietas Dodokan ditanam membentuk satu baris lurus ternyata kerusakan oleh tikus terjadi sampai dengan rumpun yang berdekatan dengan pematang. Artinya tikus ternyata juga mau menyerang rumpun padi yang berada dekat dengan pematang kemungkinan karena tikus menyenangi varietas Dodokan. Bahkan yang lebih menarik adalah, pada musim tanam gadu 2002, di Lampung Tengah khususnya Kecamatan Punggur, serangan tikus pada fase vegetatif tidak menyisakan tanaman sama sekali (puso).

Berdasarkan fakta di atas maka sangat mungkin untuk melakukan rekayasa terhadap perilaku tikus dalam menyerang atau merusak pertanaman padi, misalnya apakah pola umum kerusakan tanaman padi memang tetap (konsisten) menyerupai stadion sepakbola jika di suatu petak ditanami lebih dari satu varietas. Artinya apakah perilaku tikus sawah dalam merusak pertanaman padi bisa dipengaruhi oleh faktor yang lain, misalnya saja adalah kesukaan (preferensi) terhadap varietas tertentu.

Penelitian ini bertujuan untuk menguji preferensi makan tikus sawah (Rattus-rattus argentiventer) terhadap varietas padi Dodokan dan Cianjur kemudian sekaligus mengevaluasi pengaruhnya terhadap pola kerusakan yang ditimbulkannya di areal persawahan.

\section{METODE PENELITIAN}

Penelitian lapangan ini dilakukan di Desa Sidomulyo, Punggur, Lampung Tengah di tanah sawah (rawa) seluas satu hektar di dua tempat endemik serangan tikus. Pelaksanaan percobaan adalah dari bulan Juli sampai Desember 2006. 

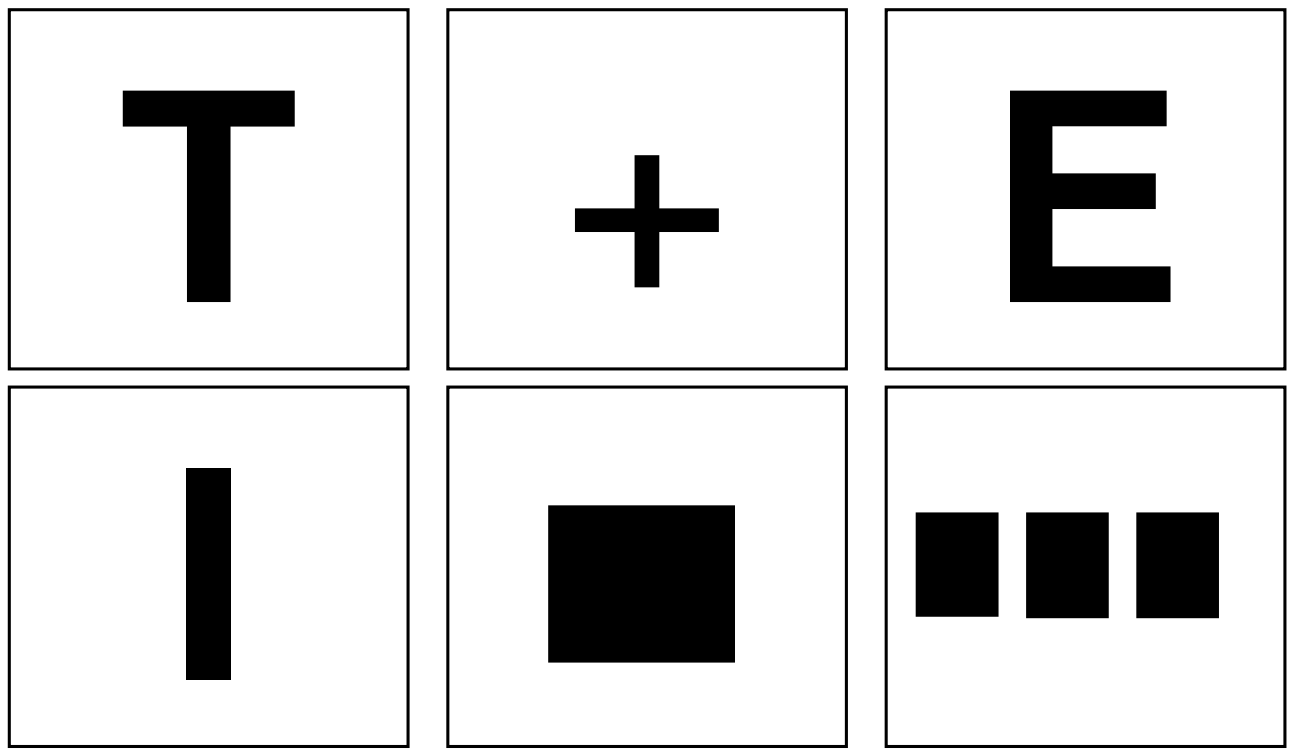

Gambar 2. Enam perlakuan pola (bentuk) penanaman varietas padi. Bagian yang dihitamkan adalah varietas Dodokan, sedangkan yang putih adalah varietas Cianjur

Percobaan ini menggunakan rancangan acak kelompok terdiri atas enam perlakuan (berupa pola penanaman) dan tiga ulangan. Satuan percobaan berupa petak pertanaman padi seluas $100 \mathrm{~m}^{2}$ yang ditanami dua varietas padi yaitu Cianjur di bagian pinggir dan Dodokan di bagian tengah. Jarak tanamnya adalah $23 \mathrm{~cm} \times 23 \mathrm{~cm}$, sehingga dalam satu petak terdapat 1849 rumpun padi. Penanaman varietas Dodokan jika dilihat dari atas akan menghasilkan enam pola atau bentuk penanaman, yaitu menyerupai bujursangkar tunggal, tiga bujursangkar berjajar, tanda plus (+), bentuk huruf I, , huruf T, dan huruf E (Gambar 2).

Variabel yang diamati adalah persentase kerusakan rumpun varietas Dodokan yang terserang oleh tikus pada hamparan yang membentuk pola seperti pada Gambar 2 dengan rumus

$$
\mathrm{P}=\frac{\text { Jumlah anakan terserang }}{\text { Jumlah anakan }} \times 100 \%
$$

Pengamatan persentase kerusakan juga dilakukan terhadap varietas Cianjur yang berada di sekitar varietas Dodokan seluas $100 \mathrm{~m}^{2}$, selebar $2,5 \mathrm{~m}$ mengelilingi petak percobaan menggunakan rumus yang sama. Hal ini bertujuan untuk mengetahui apakah kerusakan terjadi hanya pada varietas
Dodokan atau tidak. Pengamatan dimulai sejak tanaman berumur 30 hari setelah tanam (hst) sampai satu minggu menjelang panen. Untuk lebih memperjelas hasil maka dilakukan juga pemotretan tehadap semua petak percobaan dari atas lahan dengan menggunakan tangga kaki tiga (tripot) setinggi 7 meter. Pemotretan dilakukan sekali, yaitu satu minggu menjelang panen.

Hasil pengamatan berupa persentase kerusakan pada pengamatan terakhir (kumulatif) kemudian dianalisis dengan Uji F pada taraf nyata 1\%. Hasil pengamatan juga berupa gambar (foto) yang bisa digunakan untuk meyakinkan pola kerusakan pada suatu petak oleh tikus.

\section{HASIL DAN PEMBAHASAN}

\section{Hasil}

Tikus sawah mulai menyerang pertanaman padi pada umur 30 hari setelah tanam (hst) sampai dengan panen. Dalam penelitian ini pengamatan kerusakan hanya dilakukan sampai pertanaman padi berumur 84 hst (seminggu sebelum panen). Kerusakan pada varietas Dodokan untuk semua pola penanaman berkisar antara 11,00 sampai 22,33\%, terjadi pada pertanamn padi umur 30 hst, sedangkan pada pertanaman padi umur 72 hst ada dua perlakuan (pola 
penanaman yaitu berbentuk huruf $\mathrm{T}$ dan tanda +) yang sudah mencapai 100 persen (Tabel 1).

Hasil sidik ragam (Uji F) terhadap data pengamatan berupa persen kerusakan pertanaman padi pada umur 79 dan 84 hst tentu saja tidak berbeda nyata pada semua perlakuan karena semua nilai tengahnya sama yaitu $100 \%$. Hal ini berarti bahwa serangan tikus selalu tertuju pada varietas Dodokan, apapun pola penanamannya (Gambar 3). Dengan kata lain, pola penanaman tidak berpengaruh terhadap persentase kerusakan tanaman padi.
Kerusakan yang terjadi pada varietas Cianjur yang ditanam di sekitar varietas Dodokan pada 30 sampai 84 hst berkisar antara 0,00 sampai 2,67\%, jauh lebih rendah dengan kerusakan yang terjadi pada varietas Dodokan. Hasil ini memperkuat dugaan bahwa serangan tikus hanya terlokalisir (terpusat) pada varietas Dodokan saja. Untuk selengkapnya bisa dilihat pada Tabel 2.

\section{Pembahasan}

Hasil pengamatan dan analisis data

Tabel 1. Kerusakan varietas Dodokan yang berada pada tengah petakan oleh tikus pada 30 hari setelah tanam sampai seminggu menjelang panen

\begin{tabular}{|c|c|c|c|c|c|c|c|c|c|}
\hline \multirow{2}{*}{$\begin{array}{c}\text { Pola } \\
\text { Penanaman }\end{array}$} & \multicolumn{9}{|c|}{ Persen Kerusakan Tanaman Padi pada Umur (hst) } \\
\hline & 30 & 37 & 44 & 51 & 58 & 65 & 72 & 79 & 84 \\
\hline A & 11,00 & 21,67 & 32,00 & 43,67 & 48,00 & 73,33 & 100,00 & 100 & 100 \\
\hline B & 15,33 & 25,00 & 32,00 & 45,00 & 55,00 & 70,33 & 100,00 & 100 & 100 \\
\hline C & 17,67 & 21,67 & 32,33 & 55,00 & 62,67 & 76,33 & 93,33 & 100 & 100 \\
\hline D & 21,67 & 30,00 & 37,67 & 43,00 & 59,00 & 71,00 & 85,00 & 100 & 100 \\
\hline E & 22,33 & 33,67 & 43,67 & 54,67 & 62,67 & 77,00 & 93,67 & 100 & 100 \\
\hline F & 17,33 & 23,33 & 33,67 & 44,00 & 53,67 & 73,67 & 80,67 & 100 & 100 \\
\hline
\end{tabular}

Keterangan: $\mathrm{A}=$ bentuk huruf $\mathrm{T}, \mathrm{B}=$ bentuk,$+ \mathrm{C}=$ bentuk huruf $\mathrm{E}, \mathrm{D}=$ bentuk huruf $\mathrm{I}$, $\mathrm{E}=$ bentuk satu bujursangkar, $\mathrm{F}=$ bentuk tiga bujursangkar berjajar .

Tabel 2. Kerusakan varietas Cianjur oleh tikus pada luasan $100 \mathrm{~m}^{2}$ di sekitar varietas Dodokan

\begin{tabular}{cccccccccc}
\hline \multirow{2}{*}{$\begin{array}{c}\text { Pola } \\
\text { Penanaman }\end{array}$} & \multicolumn{8}{c}{ Persen Kerusakan Tanaman Padi pada Umur (hst) } \\
\cline { 2 - 9 } & 30 & 37 & 44 & 51 & 58 & 65 & 72 & 79 & 84 \\
\hline A & 0,00 & 0,00 & 2,00 & 2,67 & 2,67 & 2,67 & 2,67 & 2,67 & 2,67 \\
B & 0,00 & 0,00 & 0,00 & 0,33 & 0,33 & 0,33 & 0,33 & 0,33 & 0,33 \\
C & 0,20 & 1,33 & 0,67 & 1,00 & 1,00 & 1,00 & 1,00 & 1,00 & 1,00 \\
D & 0,00 & 0,00 & 1,33 & 1,33 & 1,33 & 1,33 & 1,33 & 1,33 & 1,33 \\
E & 0,00 & 0,00 & 0,00 & 0,00 & 0,00 & 0,02 & 0,67 & 0,67 & 0,67 \\
F & 0,00 & 0,00 & 0,00 & 1,10 & 1,10 & 1,10 & 2,00 & 2,00 & 2,67 \\
& & & & & & & & & \\
\hline
\end{tabular}

Keterangan: $\mathrm{A}=$ bentuk huruf $\mathrm{T}, \mathrm{B}=$ bentuk,$+ \mathrm{C}=$ bentuk huruf $\mathrm{E}, \mathrm{D}=$ bentuk huruf $\mathrm{I}$, $\mathrm{E}=$ bentuk satu bujursangkar, $\mathrm{F}=$ bentuk tiga bujursangkar berjajar . 
menunjukkan bahwa tikus selalu menyerang varietas Dodokan. Hal ini membuktikan bahwa tikus sawah benar-benar lebih menyenangi varietas Dodokan jika varietas tersebut ditanam bersama-sama dengan varietas Cianjur di suatu petak atau hamparan. Ada beberapa kemungkinan yang menyebabkan varietas Dodokan selalu mendapatkan serangan tikus sehingga kalau dilihat dari atas akan memperlihatkan pola serangan seperti pada Gambar 3.

Pertama, Tikus lebih menyenangi daerah tengah petakan karena lebih aman dari pengganggu, contohnya adalah predator, kucing misalnya. Kucing dan beberapa predator lainnya tidak akan masuk ke dalam petakan sawah jika kondisi petakan berair. Pernah terjadi hal yang menarik pada musim tanam gadu 2002, serangan tikus tidak menyisakan tanaman (rumpun) sama sekali, jadi serangan sampai di daerah pinggir pematang. Penyebab mengapa tikus memperlihatkan perilaku makan yang demikian perlu diteliti lebih lanjut. Bisa saja hal ini disebabkan oleh kondisi pengairan yang kurang mencukupi untuk pertanaman padi.

Kedua, Serangan tikus yang terjadi di rumpun padi yang berada di bagian tengah petakan sawah mungkin disebabkan oleh pengaruh (kadar) $\mathrm{CO}_{2}$ yang lebih tinggi di bagian tersebut. Tanaman menghasilkan gas $\mathrm{CO}_{2}$ pada malam hari dan gas ini akan terperangkap oleh rimbunnya pertanaman padi karena terjadinya turbulensi udara, berbeda keadaannya dengan daerah sekitar pematang yang sangat mudah bagi $\mathrm{CO}_{2}$ untuk bergerak. Berdasarkan hasil penelitian, tikus sangat sensitif terhadap kandungan dan laju aliran $\mathrm{CO}_{2}$ di suatu tempat (Niel et al., 2008), bahkan terhadap tipe atau kualitas air (Holm \& Ladewig, 2006) sehingga tempat tersebut menjadi disenangi atau justru tidak disenangi oleh tikus.

Ketiga, Perubahan atau perbedaan varietas yang ditanam dalam areal yang sama dapat mempengaruhi perilaku tikus. Perbedaan varietas bisa menyebabkan perbedaan kondisi lingkungan (habitat), misalnya tinggi tanaman dan jumlah anakan yang dapat mnyebabkan perbedaan kerimbunan. Hasil penelitian Novriani (2007) menunjukkan bahwa penanaman padi yang lebih awal daripada areal di sekitar suatu hamparan dapat digunakan untuk mengumpulkan tikus dan sekaligus untuk memerangkapnya. Hal ini karena pertanaman tersebut menjadi lebih rimbun daripada pertanaman sekitarnya. Sementara itu hasil percobaan Klemann \& Pelz (2006) membuktikan bahwa tikus akan melakukan perubahan perilaku makan jika menemui kondisi lingkungan yang berbeda. Sebagai contoh, penanaman bawang merah dan cabai yang dekat dengan pertanaman padi menyebabkan pertanaman bawang merah dan cabai tersebut betul-betul aman dari serangan tikus sementara tanaman padi mengalami kerusakan 35\% (Suhana et al.; 2003). Bawang merah dan cabai pada saat atau periode tertentu bisa mempunyai nilai ekonomi yang tinggi, jauh lebih tinggi daripada padi.

Keempat, Varietas padi Dodokan adalah salah satu varietas berumur pendek (genjah). Varietas yang genjah ini jika ditanam bersamaan waktunya dengan varietas yang lain yang berumur lebih panjang tentunya akan mencapai stadium generatif (primordia) yang lebih cepat. Di Tamanbogo, Lampung Timur, varietas Widas (berumur pendek) selalu mendapat serangan tikus yang lebih berat dibandingkan varietas lainnya yang berumur lebih dalam. Hasil penelitian Tristani et al. (1992) memperlihatkan pula bahwa tingkat kerusakan tanaman padi oleh tikus meningkat mulai saat primordia sampai dengan keluar malai. Pada saat primordial kemungkinan tanaman padi mengeluarkan senyawa-senyawa tertentu, misalnya saja adalah senyawa yang mudah menguap atau berupa gas (volatil). Senyawa volatil apa yang menarik bagi tikus yang dikeluarkan oleh tanaman padi saat primordia perlu dikaji. Apalagi tikus mempunyai kemampuan untuk mendeteksi senyawasenyawa tertentu termasuk yang membuat tikus menjadi sakit kalau memakannya (Gentle et al., 2005).

Hasil penelitian ini sangat bermanfaat dalam rangka pengendalian hama tikus, misalnya penanaman varietas Dodokan sebagai varietas yang disenangi tikus sebaiknya tetap di tengah petak sawah dengan bentuk yang paling mudah yaitu bujur sangkar atau huruf I (kapital). Tentu saja pengendalian tikus di areal persawaahan juga harus memperhatikan atau memadukannya dengan teknik yang lainnya, misalnya saja penggunaan perangkap bubu atau trap barrier system (TBS) dan pengumpanan. TBS ternyata merupakan cara terbaik karena dapat menghasilkan total tangkapan yang paling banyak (Suhana et al., 2003; Wibowo et al., 2003)). Disebutkan di dalam 

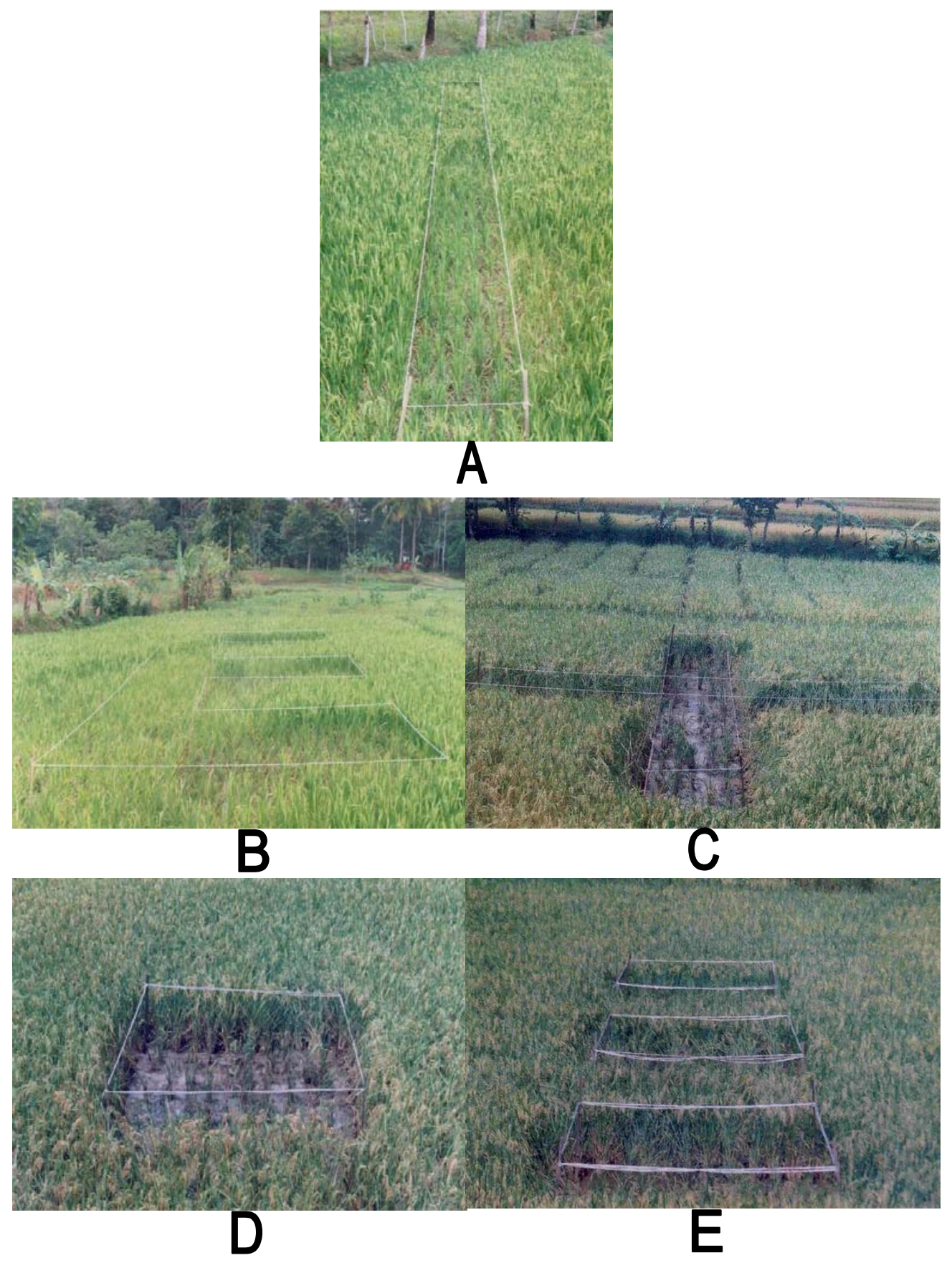

Gambar 3. Serangan tikus pada varietas Dodokan

A. Serangan membentuk pola huruf I

B. Serangan membentuk pola huruf $\mathrm{E}$

C. Serangan membentuk tanda +

D. Serangan membentuk pola bujur sangkar tunggal

E. Serangan membentuk pola 3 bujur sangkar berjajar 
Suara merdeka (2004), selain TBS bisa juga menggunakan LTBS (linear trap barrier system).

Manfaat lain dari hasil penelitian ini adalah kita bisa melokalisir atau memusatkan serangan tikus pada tengah petak yang memang dari waktu ke waktu disenangi (diserang) oleh tikus. Selanjutnya, perlu dicari proporsi varietas Dodokan yang tepat sebagai tanaman perangkap agar budidaya padi tetap menguntungkan.

\section{SIMPULAN DAN SARAN}

Berdasarkan hasil dan pembahasan dapat disimpulkan bahwa preferensi makan tikus sawah (Rattus-rattus argentiventer) terhadap varietas padi Dodokan jauh lebih tinggi daripada terhadap varietas Cianjur. Kesukaan tikus sawah terhadap varietas Dodokan menyebabkan pola kerusakan yang khas (unik), yaitu selalu mengikuti pola penanaman varietas Dodokan tersebut. Pola kerusakan ini lebih jelas lagi kalau dilihat dari atas areal (plot).

Perlu dilakukan identifikasi kemungkinan adanya senyawa volatil yang disenangi tikus, serta penelitian tentang proporsi varietas Dodokan yang tepat (optimal) yang digunakan dalam rangka pengendalian populasi tikus di areal persawahan agar budidaya tanaman padi tetap menguntungkan.

\section{DAFTAR PUSTAKA}

Budiono. 2004. Teknik pengkajian tumpangsari bawang merah dan cabai merah sebagai alternatif penanggulangan hama tikus. Buletin Teknik Pertanian 9(2): 56-60.

Gentle, M., G. Massei \& R. Quy. 2006. Diversity of diet influences the persistence of conditioned taste aversion in rats. Applied Animal Behaviour Science 97(2-4): 303-311.

Harahap, I.S. \& B. Tjahyono. 1995. Pengendalian hama dan penyakit padi. Penebar Swadaya, Salatiga. $114 \mathrm{hlm}$.

Holm, L. \& J. Ladewig. 2006. The effect of housing rats in a stimulus rich versus poor environment on preference measured by sigmoid double demand curves. Applied Animal Behaviour Science 97(2-4): 303-311.

Klemann, N. \& H.J. Pelz. 2006. The feeding pattern of the Norway rat (Rattus norvegicus) in two differently structured habitats on a farm. Applied Animal Behaviour Science 97(2-4): 293-302.

Laboratorium Pengamatan Peramalan Hama dan Penyakit Lampung Tengah. 1999. Laporan kemajuan kajian peramalan organisme pengganggu tanaman. Satuan Tugas Balai Proteksi Tanaman Pangan dan Hortikultura Provinsi Lampung. 34 hlm.

Niel, L., S.A. Stewart \& D.M. Weary. 2008. Effect of flow rate on aversion to gradual-fill carbon dioxide exposure in rat. Applied Animal Behaviour Science 109(1): 77-84.

Novriani, R. 2007. Keefektifan penggunaan tanaman perangkap (Trapping crop) pada berbagai lokasi dalam mengonsentrasikan populasi tikus sawah (Ratus spp.). Skripsi, tidak dipublikasikan. Fakultas Pertanian Universitas Lampung, Bandarlampung. $37 \mathrm{hlm}$.

Priyambodo, S. 1995. Pengendalian hama tikus terpadu. Penebar Swadaya, Yogyakarta. 135 hlm.

Radar Lampung. 2004. Presiden Megawati: Canangkan penghijauan di Lampung. Edisi Selasa, 9 Maret 2004.

Singleton, G.R. \& D.A. Petch. 1994. A Review of the biology and management of rodent pests in Southeast Asia. Australian Centre for International Agricultural Research, Technical Report 30, Canbera. 65 pp.

Suara Merdeka. 2004. Teknik baru perangkap tikus sawah. Edisi Senin, 6 September 2004.

Suhana, Ruskandi \& Sumarko. 2003. Teknik pengendalian tikus di sawah irigasi Sukamandi. Buletin Teknik Pertanian 8(2): 63-65. 
Tristiani, H.J. Priyono \& O. Murahami. 1992. Hubungan antara kepadatan populasi tikus dan kerusakan yang diakibatkannya di lahan berpagar. Laporan Akhir Kerjasama Teknis Indonesia-Jepang. Direktorat Perlindungan Tanaman, Direktorat Jendral Tanaman pangan, Jakarta.
Wibowo, L., I. G. Swibawa \& T. Muryanto. 2003. Penggunaan perangkap untuk pengendalian hama tikus sawah (Rattus rattus argentiventer). J. Hama dan Penyakit Tumbuhan Tropika 3(1): 17-20. 